\title{
Kritikusinfrastruktúra-védelmi bevetési egységek a katasztrófavédelem alkalmazásában
}

\section{Critical Infrastructure Protection Units in the Application of Disaster Management}

A Belügyminisztériumhoz tartozó Országos Katasztrófavédelmi Főigazgatóság folyamatosan fejleszti az eszközparkját, azonban a közelmúltig hiányzott egy kifejezetten vezetési pontként alkalmazható jármü, amely gyorsan telepithető és könnyen kezelhetö, illetve képes a döntéselökészitési tevékenység híradó- és informatikai hátterének önálló biztositására. Ezt a hiányt orvosolta a kritikusinfrastruktúra-védelmi bevetési egységek 2018/2019-es rendszerbe állitása. Bár az egység elsősorban a kritikusinfrastruktúra-védelmi feladatok ellátásra került a rendszerbe, felszereltségének köszönhetöen mégis jól alkalmazható bármely olyan katasztrófavédelmi beavatkozásnál, amelynél gyorsan telepíthető vezetési pontra van szükség. Jelen munka célja a jármü bemutatása és a rendszeresités óta eltelt alkalmazási tapasztalatok összegzése.

Kulcsszavak: mobil vezetési pont, információgyüjtés, katasztrófavédelem, kritikus infrastruktúra

The National Directorate General for Disaster Management (Ministry of the Interior) is constantly developing its fleet of devices; however, there has so far been a lack of a dedicated control and command point vehicle, which is quick to install and easy to operate, as well as able to provide independently the communication and IT background of decision-making processes. This deficiency has been solved by the deployment of Critical Infrastructure Protection Units in 2018-2019. The unit-despite being primarily equipped for critical infrastructure protection tasks-is well-equipped for use in any disaster management intervention that requires a quick deployment of a control

Békés Megyei Katasztrófavédelmi Igazgatóság, Orosházi Katasztrófavédelmi Kirendeltség, polgári védelmi felügyelö, e-mail: arpad.gyozo@katved.gov.hu 
and command point. The aim of the present work is to present the vehicle and to summarise the application experience since its deployment.

Keywords: mobile command point, information gathering, disaster management, critical infrastructure

\section{Bevezető}

A 21. században, az informatikai rendszerek széles körű alkalmazása, a rendkívüli mértékben felgyorsult információáramlás és -igény korában egyértelműen felértékelődött a pontos és lehetőleg valós idejü információszerzés szerepe. Különösen igaz ez a rendvédelmi szervekre, illetve a haderőre, ahol a parancsnokok, a különböző szintű vezetők és vezető szervek hatékony, valamint eredményes döntéselőkészítési-döntéshozatali mechanizmus, ezáltal az alárendeltek vezetésének alappillére a hiteles, megbízható, védett és valós idejű információk rendelkezésre állása. ${ }^{2}$ Katasztrófavédelmi szempontból kiemelt jelentőségű ez napjaink gyakori veszélyforrása, a természeti eredetű extremitás megtörténtéhez kapcsolódó károk következményeinek felszámolása során. A rendkívüli időjárási jelenségek, közös ismertetőjegye a nehéz prognosztizálhatóság, illetve a váratlan bekövetkezés, a gyors lefolyás és a nagy pusztítás, amelyek a kritikus infrastruktúra elemeit különböző mértékben károsítják vagy akár rövidebb-hosszabb időre megbénítják. ${ }^{3} \mathrm{~A}$ hazai kritikusinfrastruktúra-védelmi szabályozás által érintett szektorok: az energetika, a közlekedés, a hírközlés és az infokommunikációs infrastruktúra, a vízi közművek és a hidrológiai létesítmények, az egészségügy, az élelmiszer-előállítás és -ellátás, a kormányzat és a közigazgatás. ${ }^{4} \mathrm{~A}$ felsorolt elemeket károsító rendkívüli helyzetekben a reagálás, a szervezeten belüli és kívüli információáramlás biztosítása nem valósulhat meg a helyszínen is jelen lévő, a műveleteket irányító/támogató vezetési elem, azaz vezetési pont és az annak bázisán működő operatív munkaszerv alkalmazása nélkül. Azonban a bekövetkezett események jellegére tekintettel jelentős időveszteséget jelenthet egy állandó vezetési pont kiépítése, telepítése, amit hatékonyan valósítanak meg a mobil vezetési pontok (MVP-k). A telepíthetőségen felül az MVP-k mobilitásuknak köszönhetően képesek az események dinamikus követésére, a gyors helyváltoztatásra, valamint szükség szerint akár az önálló felderítésre is. Az MVP-k másik fö ismérve a mobilitáson túl, hogy rendelkeznek mindazon informatikai, technikai és hírközlő eszközökkel, amelyekkel a működést önállóan megkezdhetik.

Az MVP-k katasztrófavédelmi alkalmazására számos nemzetközi példa szolgál alapul. Figyelemmel jelen cikk terjedelmére a teljesség igénye nélkül csak néhányat sorolunk fel: ilyenek a német Bundesanstalt Technisches Hilfswerk, ${ }^{5}$ illetve az Amerikai Egyesült Államokban

Jobbágy Szabolcs: Híradás, hírrendszer, vezetés. Irányításirendszer-fogalmi kitekintő. Hadmérnök, 5. (2010), 1. 247-256.

3 EASAC 22. sz. szakpolitikai jelentés. Szélsőséges időjárási jelenségek Európában és hatásuk a nemzeti, valamint az uniós alkalmazkodási stratégiákra. Budapest, Magyar Tudományos Akadémia, 2014.

4 Kátai-Urbán Lajos (szerk.): Iparbiztonságtan I. Kézikönyv az iparbiztonsági üzemeltetői és hatósági feladatok ellátásához. Budapest, Nemzeti Közszolgálati és Tankönyvkiadó, 2013.

5 Lásd: www.thw.de/SharedDocs/Ausstattungen/DE/Fahrzeuge/F/F\%C3\%BCKomKW-beschr.html?nn=924418 
a Federal Emergency Management Agency6 által üzemeltetett „mobil vezetési pont”-járművek. Ezen szervezetek járműveinek vizsgálata során megállapítható, hogy a bekövetkezett természeti katasztrófák során eredményesen, a fentiekben megfogalmazott igények teljesítésével kerültek alkalmazásra, a védekezést irányító személyi állomány technikai, informatikai támogatását és gyors helyszínre juttatását biztosították.

Jelen írás fő célja a Belügyminisztériumhoz tartozó Országos Katasztrófavédelmi Főigazgatóság (BM OKF) KIBE gépjárművének bemutatása, a rendszeresítés óta eltelt alkalmazási tapasztalatok összegzése, valamint az MVP-ként való alkalmazhatóság tekintetében összehasonlítás megtétele a korábban rendszeresített „katasztrófavédelmi sugárfelderítő egység” jármüvel.

\section{A KIBE rendszerbe állítása}

A hivatásos katasztrófavédelmi szervezet tevékenységét támogató járműparkból egészen a közelmúltig hiányzott egy, a már a bevezetőben ismertetett kedvezőtlen körülmények között is biztonságosan üzemeltethető, legalább a katasztrófavédelem területi szerveinél, azaz a megyei (fővárosi) katasztrófavédelmi igazgatóságoknál (MKI) rendszerben álló, kifejezetten MVP-ként alkalmazható jármü. $A$ katasztrófavédelemnél rendszeresített MVP-k föbb jellemzői a következők szerint foglalhatók össze: a beavatkozások támogatására a riasztástól számított két órán belül helyszínre irányítható, a kiérkezést követően egyszerűen, minimális előképzettséggel és rövid idő alatt telepíthető, illetve a külső forrásoktól függetlenül, akár hosszabb igénybevétel során is, önálló müködésre képes, legalább két fő folyamatos szolgálatellátását lehetővé tevő jármü. 2014-2015-ben már megtörtént hét MKI vonatkozásában a katasztrófavédelmi sugárfelderítő egység (KSE) rendszeresítése, amelynek képességei, illetve alkalmazási tapasztalatai egy korábbi munkában részletesen elemzésre kerültek. ${ }^{7}$ Az említett cikkben történő vizsgálat összességében a KSE eredményes vezetési pontként történő alkalmazhatóságát igazolta. Hátránya azonban - mint ahogyan az elnevezés is jól mutatja - a KSE-k elsődlegesen sugárfelderítési feladatok ellátására kerültek a katasztrófavédelem rendszerébe, és pusztán másodsorban a törzsfeladatok támogatására. További hátrányként jelentkezik a KSE-k viszonylatában, hogy korlátozott számban, csak a már említett néhány MKI állományában kerültek rendszeresítésre, így esetükben az országos lefedettség, valamint a gyors reagálás nem valósult meg.

A KSE-k szolgálatba állítása óta eltelt időszakban is tovább növekedett azoknak az elsősorban rendkívüli időjárási eseményeknek a száma, amelyek miatt további hangsúlyt kaptak a kritikus infrastruktúra védelmével összefüggő beavatkozások, ezzel párhuzamosan továbbá nőtt az igény az ilyen helyzetekben alkalmazható MVP-kre. A hivatásos katasztrófavédelem alaprendeltetései közé nemcsak a klasszikusnak nevezhető tűzoltás, műszaki mentés, polgári

Lásd: www.mbfindustries.com/fema/

Négyesi Imre - Győző-Molnár Árpád: Katasztrófavédelmi sugárfelderítő egység mobil vezetési pontként történő alkalmazása. Hadtudományi Szemle, 12. (2019), 2. 129-138. 
védelem tartozik, hanem kiemelt helyen jelentkeznek az iparbiztonsági, hatósági, továbbá a kritikus infrastruktúra védelmével összefüggő feladatok is. ${ }^{8}$ E feladatok végzését a katasztrófavédelmi szervezet állománya pusztán az esetek kis részében tudja önállóan megoldani. A különböző kritikusinfrastruktúra-elemekből fakadó sajátosságokra figyelve a kárfelszámolási folyamatba mindenképpen szükséges bevonni az érintett infrastruktúra üzemeltetőjét, a társszervet. E folyamat ebböl következően több szereplő együttmüködését, koordinált tevékenységét igényli, lehetőleg egy kárhelyszínhez közeli telepítési helyen. A fenti elvárások figyelembevételével megtervezett kritikusinfrastruktúra-védelmi bevetési egységek (KIBE) rendszeresítését a KEHOP-1.6.0-15-2016-00024 azonosító számú projekt tette lehetővé, amelynek célja egy egységes, a komplex ellenőrzések lebonyolítását segítő, a megelőző hatósági munkát, vezetői döntéshozatalt, továbbá az események gyors és hatékony kezelését támogató rendszer megvalósítása. ${ }^{9}$ Az említett KEHOP-projekt eredményeképpen összesen 20 db KIBE került beszerzésre, azaz a katasztrófavédelem valamennyi területi szervénél szolgálatba állhatott egy ilyen jármü.

\section{A KIBE feladatai és föbb jellemzői}

A KIBE járművek feladatrendszerét és tevékenységét a hivatásos katasztrófavédelmi szervezeten belül a BM OKF főigazgatói intézkedése határozza meg. Az intézkedést alapul véve, illetve az abban foglaltakat vizsgálva megállapítható, hogy a KIBE elsődleges feladata a létfontosságú rendszerelemekben bekövetkezett rendkívüli események, továbbá a természeti és civilizációs katasztrófák esetén a beavatkozó erők koordinálására, irányítására szolgáló vezetési pontként történő működés, ezáltal a lakosság és az anyagi javak védelme. MVP-ként való alkalmazásnál az egység feladatai különösen:

a) „a létfontosságú rendszerelemben bekövetkezett esemény kárterületének nagyságát, kiterjedését, jelentőségét illető felderítésben háttértámogatás nyújtása;

b) a beavatkozói állomány, a lakosság, valamint az anyagi javak veszélyeztetettségét érintő felmérésben való közreműködés, a változások figyelemmel kísérése, az azokról szóló adatok, információk gyűjtése és továbbítása;

c) a kárhelyparancsnok döntéseinek előkészítéséhez javaslatot tesz a beavatkozás biztonságának, hatékonyságának elősegítése érdekében;

d) kapcsolat tartása a létfontosságú rendszerelem helyszínen lévő munkatársával, biztonsági összekötőjével;

e) szakmai segítség nyújtása a társ- és együttműködő szervezetek részére."10 
A KIBE a kárhelyszíni szakmai informálódási és irányítási tevékenységet segíti elő, valamint támogatást nyújt a vezetői döntések előkészítéséhez. A gépjármüben kiépített informatikai és távközlési-telekommunikációs eszközök lehetővé teszik:

a) a világhálón megtalálható, a katasztrófavédelmi feladatok végrehajtását támogató adatbázisok elérését;

b) a katasztrófavédelmi megelőzési, beavatkozási és lakosságvédelmi intézkedésekkel kapcsolatos információk gyűjtését, elemzését és értékelését;

c) a döntéselökészítéshez gyűjtött adatok átadását a BM OKF, az MKI igazgatója és igazgatóhelyettese, a helyi szervek, a kárhelyparancsnok, a megyei főügyeletek, műveletirányítási ügyeletek és a Katasztrófavédelmi Mobil Laborok számára;

d) az eseménnyel kapcsolatos dokumentumok kezelését, jelentések készítését;

e) a társszervekkel való együttműködést, kommunikációt.

A KIBE az előzőekben említett, kárfelszámoláshoz köthető vezetéstámogató feladatai mellett azonban mindenképpen fontos megemlíteni még azt is, hogy az egység többcélú igénybevételre került rendszeresítésre. A katasztrófavédelem tevékenysége során számos olyan „békeidőszaki” feladat van, amelyben felszerelésének köszönhetően eredményesen müködhet közre. Erre tekintettel a katasztrófavédelem különböző hatósági - tűzvédelmi, iparbiztonsági, vízvédelmi - jogköreihez tartozó ellenőrzésekbe és szakterületi gyakorlatokba kiemelten bevonásra kerülhet a jármü. A KIBE prognosztizálható, elsősorban a már említett hatósági tevékenységéhez kapcsolódóan az MKI havi munkatervet készít, amely lehetővé teszi a tervszerü és gazdaságos igénybevételt. ${ }^{11}$

A KIBE tervezése és gyártása a BM HEROS Zrt.-nél folyt, amelyet a Belügyminiszter 2001-ben alapított, annak érdekében, hogy a Belügyminisztériumhoz tartozó szervezetek, intézmények által üzemeltetett gépjármüvek és technikai eszközök szakszerű és folyamatos javítása, szervizelése, karbantartása, esetenként gyártása biztosított legyen. A KIBE alapját egy Volkswagen T6 HT 2.0 TDI SCR BMT típusú, dobozos felépítményủ jármű adja. Főbb műszaki paraméterei megegyeznek a kereskedelmi forgalomban kapható hasonló gépjárművekéivel, azaz a motorja: 1968 ccm, dízel, 110 kW/150 Le, erőátvitele: kézi 6+1 sebességi fokozatú; megengedett legnagyobb össztömege: 2800 kg, hosszúsága: 5304 mm, magassága: 2477 mm, szélessége: 1900 mm. Az MVP jellegü alkalmazáshoz átalakított csomagtér (munkatér) adatai: 9,3 m³ , hosszúság: 2975 mm, szélesség: 1700 mm, magasság: 1940 mm. A munkatér hátsó részén polcos málhatér található. A munka- és a málhatér hö- és hangszigetelt burkolattal van ellátva. A KIBE vezetőfülkéjének tetején kék-piros LED-es és forgófényes fényhíd, az elején és a hátulján 1-1 db kék és piros kiegészítő megkülönböztető LED-es villogó, továbbá tolatókamera és kihangosításra is alkalmas elektronikus megkülönböztető hangjelző-berendezés került elhelyezésre. A jármű a megkülönböztető jelzésen felül a rendvédelmi szervezeti jellegre utaló és egyben a láthatóságot erősítő matricázással ellátott. ${ }^{12}$

10/2021. számú BM OKF intézkedés. i. m.

12 Kritikus Infrastruktúra Bevetési Egység. Használati útmutató. A BM Heros Zrt. kiadványa. 


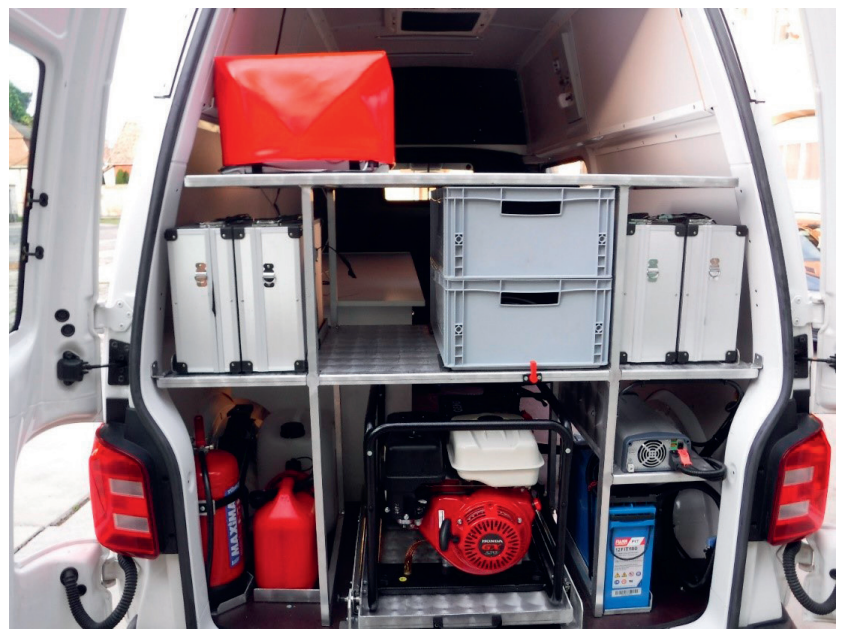

1. ábra. A beépített polcos málhatér és a KIBE-re málházott eszközök

Forrás: Tira Róbert főhadnagy fotója

A KIBE-n elhelyezett felszerelést vizsgálva kijelenthető, hogy azon a kárhelyszíni és az egyéb tevékenység korszerü, önálló informatikai tevékenykedést lehetővé tevő eszközök találhatók. ${ }^{13}$

Az egység a saját erőkkel, illetve a társszervekkel történő, vezeték nélküli hírközlési kapcsolattartására két, a vezetőfülkében és a munkatérben külön beépített, GPS-vevővel, Gateway típusú választható átjátszó funkcióval és kézi beszélővel felszerelt, Sepura SRG3900 EDR-terminál szolgál.

Az informatikai támogatást két HP ProBook 450 G5 típusú laptop biztosítja, amelyeken megtalálhatók és futtathatók mindazok az alkalmazások, valamint adatbázisok, amelyek a katasztrófavédelem alkalmazását segítik. Mind a hatósági munkát, mind a törzsalkalmazást jól támogatja a málházott lézernyomtató, amely kellően nagy kapacitású ahhoz, hogy az okvetlenül szükséges papíralapú dokumentumok rendelkezésre állását biztosítsa. A napjainkban nélkülözhetetlen internetelérhetőséget, egy V-link WL-R520 LH-dm 4G router, a hálózati tevékenységet egy Cisco 8-port gigabit switch biztosítja.

A berendezések üzemeltetéséhez szükséges áramellátás a jármű motorjáról, külső megtáplálással vagy a rendszeresített GEKO 4400 típusú, $~ 5,4$ kW teljesítményű aggregátorral biztosított, illetve - rövidebb időtartamú igénybevételre - az egység saját 12V-os, 180 Ah-s akkumulátoráról. Az aggregátor egy üzemanyag-feltöltéssel a terheléstől függően 2-4 óra időtartamban biztosítja az egység önálló működését. Az áramfejlesztő használatához azt a málhatérből szükséges kiemelni és a biztonsági előírásoknak megfelelően telepíteni. A KIBE a jobb oldalán elhelyezett csatlakozóknak köszönhetően egyaránt alkalmas a saját internetes és áramhálózat külső megosztására, illetve megtáplálására, valamint a jármű áramigényének külső hálózatról történő biztosítására.

13 Kritikus Infrastruktúra Bevetési Egység. i. m. 
A KIBE időjárási viszonyoktól függetlenül történő bevethetőségét és a komfortos munkavégzést biztosítja az utastérben elhelyezett tetőklíma. A járművet felszerelték továbbá egy Concorde Roadcam HD80 GPS típusú eseményrögzítő kamerával, Fuji Finepix XP120 digitális fényképezőgéppel, valamint egy Navon A500 5" müholdas helymeghatározó berendezéssel.

Az előzőleg bemutatott különböző informatikai és kapcsolódó technikai berendezéseken túl málházásra került és a különféle, végzett tevékenységek támogatására szolgál: hat db öszszecsomagolható, akkus izzós terelőkúp, a kordonszalag, a kézilámpa, illetve kéziszerszámok, valamint a müködéshez szükséges egyéb irodai eszközök.

A KIBE nem rendelkezik állandó kezelőszemélyzettel, a használókat eseti jelleggel az MKI igazgatója vagy annak helyettese jelöli ki, a következő szempontok figyelembevételével. A KIBE mindenkori állománya minimum két fő - egy parancsnok és egy gépjárművezető -, akik közül a málházott szakfelszerelések és kisgépek kezeléséhez szükséges képesítéssel egy főnek rendelkeznie kell. Az áramfejlesztő üzemeltetéséhez előirás, hogy a kezelő állománynak kezelői tanfolyamon kell részt vennie és eredményes vizsgát tennie. A gépjármű vezetéséhez minimum „B"-kategóriás vezetői engedély és kétéves vezetési gyakorlat szükséges. A KIBE működőképességének, bevethetőségének, illetve rendszeres karbantartásának biztosítása az üzemeltető MKI feladata. A KIBE kezelőszemélyzetébe tervezhető állományt legalább évente egy alkalommal képzésben kell részesíteni. ${ }^{14}$

\section{A KIBE alkalmazási lehetőségei}

Az alkalmazás vizsgálatához szükséges a fentiekben ismertetett KIBE jármü egyes tulajdonságait a hozzá méretében, felépítésében és feladatában is hasonló KSE-vel összevetni. Célszerü az összehasonlítás, különösen abból a szempontból, hogy a KIBE és a KSE rendszeresítése között rövid idő telt el, és mindkét jármű alkalmas MVP-feladatok ellátására.

Az összehasonlítás során, az elsőként megállapítható markáns különbség - amelyet már többször említettünk -, hogy a KSE jármű alapvetően sugárfelderítési feladatokra került rendszeresítésre, és a vezetési pontként történő használata az erre alkalmas berendezései ellenére is csak másodlagos. Ezzel ellentétben a KIBE már kiemelten az MVP-feladatokra történő alkalmazást figyelembe véve került megtervezésre.

Mindezek jól tetten érhetők a járművek belső terében, mivel - a jármű alapvetően nagyobb mérete ellenére - a KSE az elhelyezett sugárfelderítési felszerelések, berendezések miatt jóval zsúfoltabb. A KIBE munkaterében ezzel szemben csak a málhatér és két asztal került beépítésre, így nem pusztán két fő végezheti a törzsfeladatait, hanem szükség esetén még bővíthető a törzsmunkát végző állomány, anélkül, hogy egymás tevékenységét lényegesen akadályoznák.

Kifejezetten jelentős különbség - ahogyan a belső térről készült képekből is kitűnik -, hogy a KSE beépített munkaállomásaival szemben, a KIBE jármúben nem kerültek állandó munkaállomások kiépítésre. Az informatikai támogatást itt két laptop biztosítja, amely erősíti az alkalmazhatóság szabadságát, mivel e két eszköz igény szerint kiemelhető a járműből,

14 10/2021. számú BM OKF intézkedés. 
és a beavatkozás jellegétől, akár attól függetlenül is üzemeltethető. A laptopok alkalmazása elősegíti továbbá, hogy az eszközök esetleges hibája vagy avulása esetén ne legyen szükség a munkaállomás megbontására, ehhez társul, hogy a laptopok alkalmazása némileg egyszerübb a felhasználók számára is.

Mindkét jármű saját aggregátorral van felszerelve, ezek lehetővé teszik az önálló, külső áramforrástól független tevékenység végzését, ami megteremti annak lehetőségét, hogy a megfelelő üzemanyag-ellátás és karbantartás biztosításával akár huzamosabb időn keresztül is megoldott legyen az egységek müködése. Ugyanilyen lényeges, hogy mindkét egység rendelkezik a munkatérben klímaberendezéssel, amelyek biztosítják a kezelők számára a komfortos környezetet, bármilyen időjárási körülmények között is kell a tevékenységet végezni. Mindkét egység működtethető külső áramforrásról is, amihez a betáplálási pontok kiépítésre kerültek.

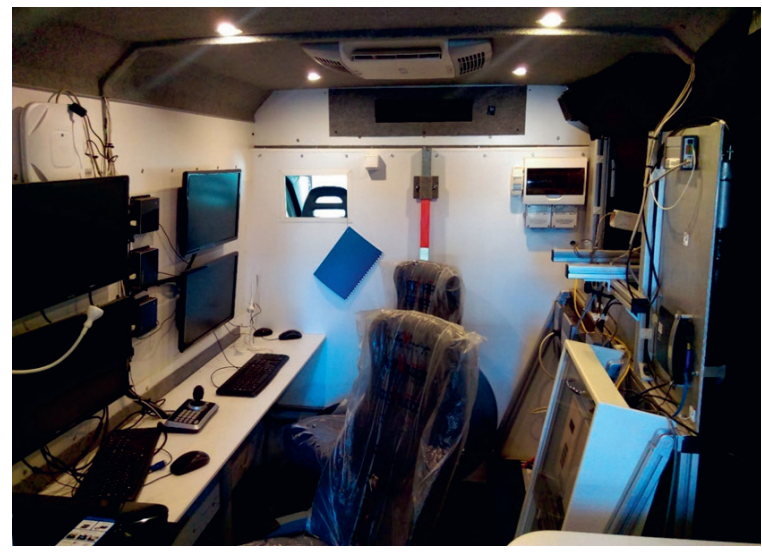

2. ábra. A KSE belseje a kisebb, zsúfoltabb munkatérrel

Forrás: Gombos Erik föhadnagy fotója

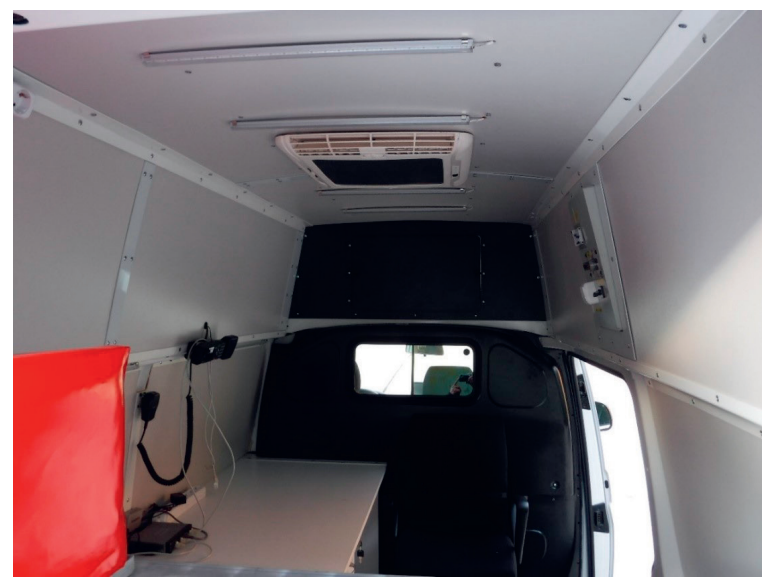

3. ábra. A KIBE letisztult munkatere

Forrás: Tira Róbert föhadnagy fotója 
A KIBE- és a KSE-járművek gyors bevethetőségét egyaránt biztosítja, hogy a járművek - megkülönböztető jelzés nélküli - vezetéséhez elegendő a „B” kategóriás gépjárművezetői engedély. Ennek köszönhetően az állomány bármely kijelölt tagja vezetheti őket, nem szükséges külön képesítéssel rendelkező gépjárművezető igénybevétele.

Hasonlóság figyelhető meg a két egység között abban is, hogy kezelőszemélyzetük egyaránt két fö, és eseti jelleggel kerül beosztásra, azonban a két fö alkalmazása bizonyos esetekben kevésnek bizonyulhat, különösen a jármű megtelepítésének és az elektromos, illetve informatikai rendszere kiépítésének időszakában. A KIBE rendszeresített aggregátorával kapcsolatban szükséges megjegyezni, hogy annak tömege $\sim 71 \mathrm{~kg}$. Emiatt a biztonságos, munkavédelmi előírásoknak is megfelelő lemálházáshoz és üzembe helyezéshez nem elegendő a gépjármü kétfős kezelőállománya, szükséges még legalább két fő bevonása.

A KIBE és a KSE közötti hasonlóság, hogy elsődlegesen a szilárd burkolatú, kiépített utakon való mozgásra tervezték őket, így terepjáró képességük korlátozott, amit a bevetésük előtt mindenképpen figyelembe kell venni.

Jelentős eltérés a két jármű között, egyidejüleg komoly elörelépés, hogy a KIBE valamenynyi MKI állományában rendszeresítésre került, ennek következtében biztosítható valamennyi megyében a gyors reagálás.

A rendszerbe állítás óta eltelt időszakban KIBE-k fokozottan kerülnek bevonásra a katasztrófavédelem feladataiba, amelyek közül kiemelendő az iparbiztonsági szakterület által végzett veszélyes áruk közúti és vasúti szállításának ellenőrzése, illetve a szakterületet is érintő gyakorlatokon való részvétel. A veszélyes áruk szállításának ellenőrzéséhez kapcsolódó hatósági feladatokat nagyban elösegítik a KIBE ismertetett informatikai rendszerei, illetve az egyéb eszközökkel történő ellátottsága, amelyekkel a helyszíni hatósági tevékenység végzése gördülékenyebben és biztonságosan valósítható meg. Az ellenőrzést végzők tapasztalatai szerint a jármüben rendelkezésre álló eszközök az ellenőrzési tevékenység időtartamát jelentősen lerövidítik, eredményességét fokozzák, köszönhetően az irodai és informatikai eszközöknek, amelyek biztosítják a folyamatos kapcsolatot és hozzáférést a katasztrófavédelmi adatbázisokhoz.

A KIBE rendszeresítésének helyességét és az egység képességeit - különösen az önálló MVP-működésre és külső eszközök megtáplálási lehetőségének kiépítésére vonatkozóan - egy katasztrófafelszámolási együttmüködési gyakorlaton szerzett tapasztalatok támasztják alá. A 2019. november 20-án, Tótkomlóson végrehajtott gyakorlat feltételezése szerint egy vasúti tömegszerencsétlenséget követően a helyszíni irányítási feladatok biztosítása, helyszíni operatív törzs létrehozása válik szükségessé. A helyszíni operatív törzs a helyi műveletirányítást igénylő események eredményes helyszíni kezelése, a döntések szakszerű előkészítése érdekében a kialakult helyzet függvényében létrehozott ideiglenes müveletirányítási elem, amelynek működési helye a kárhelyszín körzetében kijelölt vezetési pont. A feladatok volumenére és a bevetett erők összetételére (önkormányzat, katasztrófavédelem, önkéntes tűzoltó- és mentőszervezetek) figyelemmel azonban a jármű munkaterének befogadóképességét meghaladó létszámú munkaszerv kerül alkalmazásra. Ennek elhelyezése érdekében a gyakorlatot végrehajtó Békés MKI kezelésében lévő felfújható sátor került telepítésre. A sátor felfújását elektromos pumpa alkalmazásával kellett végrehajtani, amelynek áramellátását 
a KIBE aggregátora biztosította. Az említett felfújható sátor berendezését követően az operatív munkaszerv működéséhez szükséges informatikai eszközök a KIBE-ből kerültek biztosításra. A KIBE aggregátora, valamint a jármü a gyakorlat teljes időtartama alatt eredményesen biztosította a szükséges áram- és internetellátást, továbbá a folyamatos EDR-kapcsolatot a beavatkozók és az elöljáró, továbbá a társszervek között.

A gyakorlat jó alkalmat biztosított arra, hogy a kezelésbe bevonható állomány átfogó ismereteket szerezzen a KIBE jármű működtetési feladatairól, illetve eredményesen modellezte a jármủ bevonásával végrehajtható törzstámogató feladatokat.

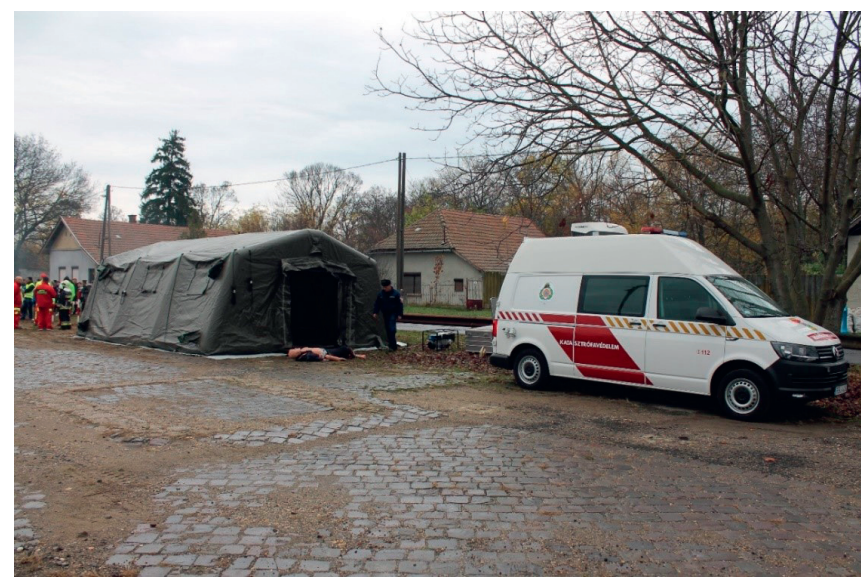

4. ábra. KIBE mobil vezetési pontként való használata katasztrófafelszámolási együttműködési gyakorlat során

Forrás: Gombos Erik hadnagy fotója

\section{5. Összegzés}

A KIBE rendszeresítésével, az átgondolt tervezésnek és fejlesztési folyamatnak köszönhetően, a hivatásos katasztrófavédelmi szervezet egy jól használható MVP-vel gazdagodott. A jármü és a málházott eszközök lehetővé teszik a bevezetőben megfogalmazott igények teljesülését, emellett megfelelnek a 21. századi műszaki követelményeknek. Azaz a KIBE önállóan képes biztosítani a vezetés folyamatosságát és a döntéselőkészítési tevékenység híradó- és informatikai hátterét, még kedvezőtlen külső üzemeltetési körülmények között is.

A KIBE szolgálatba állításának kiemelkedő eredménye, hogy valamennyi MKI-n rendszeresítésre került, ezáltal növelve a katasztrófavédelmi szervezet beavatkozásainak hatékonyságát. Mindemellett a katasztrófavédelem sokrétű alaprendeltetésére figyelemmel a mindennapi tevékenység során is hatékonyan alkalmazható, amit jól alátámasztanak a hatósági ellenőrzések végrehajtása során szerzett pozitív tapasztalatok.

Az egység használhatóságát nagyban elősegíti, hogy kezeléséhez nem kell speciális ismeretekkel rendelkezni, ezáltal a hivatásos állomány bármely tagja előképzettség nélkül képes kezelni a benne elhelyezett technikai, informatikai eszközöket, ami alól kizárólag az aggregátor 
képez kivételt. Ennek ellenére a hivatásos katasztrófavédelmi szervezetnek törekednie kell arra, hogy folyamatos képzéssel és gyakorlással szinten tartsa a KIBE kezelőszemélyzetébe tervezhető állomány jártasságát, illetve hogy az esetlegesen új belépő állománytagok is elsajátíthassák a működtetés alapjait. Erre figyelemmel javasolt az állomány lehetőleg félévenkénti felkészítése. Ehhez kapcsolódóan javasolt a Nemzeti Közszolgálati Egyetem Rendészettudományi Karának Katasztrófavédelmi Intézete, illetve a Katasztrófavédelmi Oktatási Központ hallgatói részére a tananyagba beépíteni a KIBE kezelésének alapjait. Mindez azzal az előnnyel jár, hogy a későbbiekben akár a hatósági feladatokba, akár a törzsek tevékenységébe tervezhető állomány már az iskolarendszerű képzés időtartama alatt megszerzi az üzemeltetéshez szükséges kompetenciákat.

Az eddigi alkalmazási tapasztalatok alapján különösen az aggregátor lemálházásánál és üzembe helyezésénél figyelmet kell fordítani arra, hogy a KIBE kezelőszemélyzetén kívül még legalább két fő részt vegyen a felmerülő feladatokban, amivel biztosítható az áramfejlesztő biztonságos, a munka- és balesetvédelmi előírásoknak megfelelő telepítése.

A KIBE, paramétereit figyelembe véve, elsősorban arra lehet alkalmas, hogy egy településen vagy egyéb kisebb, behatárolható területen bekövetkező rendkívüli esemény során elláthassa a kihelyezett vezetési pont szerepét. Azonban a nagyobb területet érintő katasztrófák, a több beavatkozó szervezet összehangolt tevékenységét igénylő, összetett káresemények nagyobb létszámú és összetett struktúrájú vezetési törzsek alkalmazását indokolják, amelyeknek a jármű méretbeli korlátai miatt már nem felel meg maradéktalanul. Ezzel együtt - ahogyan az ismertetett katasztrófafelszámolási együttműködési gyakorlat során is megvalósításra került - a KIBE alkalmas azon törzs tevékenységét is eredményesen támogatni, amelynek működése nem a jármű munkaterében valósul meg. Ez jól alátámasztja azt a koncepciót, hogy a rendszeresített eszközök a KIBE-ből egyszerüen kiemelhetők, és máshol is alkalmazhatók, ezzel nagymértékben fokozzák az alkalmazási szabadságot, amire a káresemények felszámolása során az irányítást végző állománynak a körülmények dinamikus változása miatt szüksége van.

A KIBE - figyelembe véve a rendszeresítése óta eltelt időszak tapasztalatait - összességében jól alkalmazható arra, hogy a kialakult helyzet függvényében akár a hatósági tevékenység végzésének bázisául szolgáljon, akár a helyi műveletirányítást igénylő események kezelésében részt vegyen, vagy akár a döntések szakszerű előkészítése érdekében ideiglenes műveletirányítási elemként megalakított, kis létszámú operatív munkaszerv tevékenységét támogassa.

\section{Felhasznált irodalom}

Dely Péter: A kritikus infrastruktúra védelmének hazai jogszabályi környezete. Hadmérnök, 12. (2017), 3. 188-197. Online: https://doi.org/10.32567/hm.2017.3.17

Horváth Margit (szerk.): Elemzés a katasztrófavédelem új rendszerének müködéséről. Budapest, Állami Számvevőszék, 2016.

Jobbágy Szabolcs: Híradás, hírrendszer, vezetés. Irányításirendszer-fogalmi kitekintő. Hadmérnök, 5. (2010), 1. 247-256. Online: http://hadmernok.hu/2010_1_jobbagy.pdf

Kátai-Urbán Lajos (szerk.): I parbiztonságtan I. Kézikönyv az iparbiztonsági üzemeltetöi és hatósági feladatok ellátásához. Budapest, Nemzeti Közszolgálati és Tankönyvkiadó, 2013. 
KEHOP-1.6.0-15-2016-00024 Kritikusinfrastruktúra-védelmi bevetési egységek rendszerbe állitása. Belügyminisztérium, Országos Katasztrófavédelmi Főigazgatóság. Online: www.katasztrofavedelem.hu/611/szechenyi-2020/22/kritikusinfrastruktura-vedelmi-bevetesi-egysegek-rendszerbe-allitasa\#galleries

Kritikus Infrastruktúra Bevetési Egység. Használati útmutató. A BM HEROS Zrt. kiadványa.

Máthé András - Berek Lajos: Mobil vezetési pontok a krízismenedzsmentben. Hadmérnök, 15. (2020), 2. 127-143. Online: https://doi.org/10.32567/hm.2020.2.9

Négyesi Imre - Győző-Molnár Árpád: Katasztrófavédelmi sugárfelderítő egység mobil vezetési pontként történő alkalmazása. Hadtudományi Szemle, 12. (2019), 2. 129-138. Online: https://doi. org/10.32563/hsz.2019.2.9

\section{Szakpolitikai források}

A BM Országos Katasztrófavédelmi Főigazgató 10/2021. számú intézkedése az iparbiztonsági szakterületen speciális feladatot ellátó szerek tevékenységének szabályozásáról

EASAC 22. sz. szakpolitikai jelentés. Szélsőséges időjárási jelenségek Európában és hatásuk a nemzeti, valamint az uniós alkalmazkodási stratégiákra. Budapest, Magyar Tudományos Akadémia, 2014. Online: https://easac.eu/fileadmin/PDF_s/reports_statements/Extreme_Weather/Extreme_Weather_Hungarian.pdf 